\title{
Acute Toxicity of Cypermethrin on Nile tilapia Fry
}

\author{
Anan KENTHAO ${ }^{1,2}$, Wanchat SIRISARN ${ }^{1,3}$ and \\ Pornpimol JEARRANAIPREPAME,
}

\author{
${ }^{1}$ Department of Biology, Faculty of Science, Khon Kaen University, Khon Kaen 40002, Thailand \\ ${ }^{2}$ General Science Programme, Faculty of Science and Technology, Thepsatri Rajabhat University, \\ Lopburi 15000, Thailand \\ ${ }^{3}$ Faculty of Science and Technology, Songkhla Rajabhat University, Songkhla 90000, Thailand
}

('Corresponding author's e-mail: porjea@kku.ac.th)

Received: 20 April 2017, Revised: 19 February 2018, Accepted: 10 March 2018

\begin{abstract}
The present study aimed to evaluate the acute toxicity effect of cypermethrin contaminated aquatic ecosystems by using a 30 days post-hatching fry of Nile tilapia as a test model. The control and six test experiments, each comprising 10 animals, were repeated three times and evaluated with the static test method. The lethal concentrations at $50 \%\left(\mathrm{LC}_{50}\right)$ and $70 \%\left(\mathrm{LC}_{70}\right)$ for $96 \mathrm{~h}$ were determined using the probit analysis. Behavioural and histological changes were observed in fish exposed with cypermethrin at both $96 \mathrm{~h} \mathrm{LC}_{50}$ and $96 \mathrm{~h} \mathrm{LC}_{70}$. The values of $96 \mathrm{~h} \mathrm{LC}_{50}$ and $96 \mathrm{~h} \mathrm{LC}_{70}$ were estimated at 32.496 and $40.311 \mathrm{ppb}$, respectively. The affected fish exhibited the loss of equilibrium with erratic and darting swimming movements, hyperactivity, secretion of mucous and increasing rate of opercula activity. Severity of histopathological lesions were related to concentration levels and exposure times. The histological changes of gill tissues included the swelling of epithelial cells and the fusion of secondary lamella. An enlargement of sinusoids, pyknotic nuclei, vacuole formation and degeneration in hepatic parenchyma were observed in liver. The degeneration of glomerulus combining with oedema of renal tubule was also noticed in kidney. No alter lesion was seen on skin tissue. The results in the present study suggest that low levels of cypermethrin in the aquatic environment may alter adverse effect on growth and development in Nile tilapia.
\end{abstract}

Keywords: Toxicity bioassay, Lethal concentration, Histopathological alteration

\section{Introduction}

Nile tilapia, Oreochromis niloticus (Linnaeus, 1758) is a commercial freshwater fish in the family Cichidae, which can grow, develop and propagate rapidly [1,2]. Tilapia aquaculture increasingly plays a vital role in the economy of Thailand. During the last decades, tilapia has become the most popular species in finfish aquaculture. In fact, an averaged of 217.76 thousand-tons of tilapia are produced in Thailand annually [3]. Besides, most of the cultivated tilapia takes place in ponds and reservoir as well as cage farming in canals and rivers [1,3].

Unfortunately, along with the development of agricultural production in Thailand, there have been a remarkable increase in the use of more powerful agriculture chemicals such as synthesised fertilizers and pesticides [4,5]. The intensive uses of such chemicals lead to the hazardous effect on human health as well as on the environment. Moreover, the contamination of pesticides in aquatic system can lead to the mortality or reduction in the productivity of various fish as well as tilapia [6,7]. Cypermethrin is a synthetic pyrethroid insecticide used against a broad range of pets in agriculture, public health, and animal husbandry [8]. It is considered as one of the top-ten insecticides used in Thailand [9] because of its broad spectrum and less toxicity compared to other groups of insecticides such as organochloride and 
organophosphate [10]. Unfortunately, when this pesticide move from the place of application into aquatic ecosystem, it ultimately leads to the mass mortality of non-target organisms and undesirably desperate perturbations of the environment $[8,11]$.

Many previous studies suggested that cypermethrin is highly toxic to fish and aquatic invertebrates compared to birds and mammals $[8,12,13]$. In aquaculture of Nile tilapia, it seems to be noticed that agricultural workers are not aware of the toxic effect of cypermethrin as this has been widely used without any concerns [5]. In addition, tilapia could also tolerate the insecticide at very low concentration without any physical abnormalities [14]. Although physical characteristics do not change, internal organs have some abnormalities that need some biological techniques to determine those abnormalities. Therefore, in the present study, it aimed to evaluate the effect of cypermethrin on the behavioural changes, survival rates, and histological alterations of gill, liver, kidney and skin of Nile tilapia $(O$. niloticus) fry which is exposed to different concentrations of cypermethrin.

\section{Materials and methods}

\section{Preparation of fish sample and stock solution}

Nile tilapia fry of a 30 days post-hatching were obtained from Khon Kaen Inland Fisheries Research and Development Centre. The fish were acclimatised in dechlorinated water for 10 days prior to testing. The test fish were kept in glass tank size $50 \times 100 \times 80 \mathrm{~cm}^{3}$ at ambient temperature suppling with aerated water and were fed with commercial food pellets twice daily.

Stock solution of cypermethrin with a concentration of $100 \mu \mathrm{g} / \mathrm{l}$ was prepared by diluting a commercial cypermethrin $10 \%$ EC insecticide in distilled water.

\section{Toxicity test for lethal concentration}

Toxicity tests were carried out to determine lethal concentration (LC) following FAO procedure for short-term static bioassays [15] and APHA standard protocol [16].

Initially, the fish were exposed to cypermethrin test concentrations of, $0,2,4,6$ and $8 \mu \mathrm{g} / \mathrm{l}$ to find out the activity range of the materials under the test. Healthy fish $(n=10)$ were maintained in 10 litre of experimental water with different concentration of cypermethrin. Two replicates were applied for the test in duration of $96 \mathrm{~h}$. The concentration value that caused all fish death was used as a maximum limit of concentration for further experiments.

To determine the lethal concentration (LC) of cypermethrin for 50 and $70 \%$ mortality $\left(\mathrm{LC}_{50}\right.$ and $\mathrm{LC}_{70)}$, seven-levelled of cypermethrin concentrations $(1,2,3,4,5$ and $6 \mu \mathrm{g} / \mathrm{l})$ were used as experimental waters. Healthy fish $(\mathrm{n}=10)$ were put in a test tank with 10 litre of experimental waters, and three replicates were set up. Similarly, a control was set up with water lacking cypermethrin. The fish were not fed one day before the experiment and during the experimental period. The number of dead fish in each replicate was recorded after $96 \mathrm{~h}$ exposure. The $\mathrm{LC}_{50}$ and $\mathrm{LC}_{70}$ were then determined using the probit analysis $[17,18]$, and the fish behaviours were also observed daily at the same time.

\section{Acute toxicity test}

Toxicity tests were set up with two replicates of a set of three cypermethrin concentrations (control, $\mathrm{LC}_{50}$, and $\left.\mathrm{LC}_{70}\right)$. The fish were not fed for $24 \mathrm{~h}$ prior to their use in the experiments and during the experimental period. The fish were sacrificed at a subsequence time of 24, 48, 72 and $96 \mathrm{~h}$ post-exposure for histopathological examination. Samples of gill, liver, kidney and skin were cut into small pieces and fixed in $10 \%$ neutral buffered formalin for at least $24 \mathrm{~h}$. The fixed tissue samples were processed for paraffin infiltration using standard paraffin method. The tissue blocks were sectioned at a $5 \mu \mathrm{m}$ thickness using microtome and stained with Haematoxylin and Eosin (H\&E) staining. The stained tissues were then examined under light microscopy for their alterations. The photos were also taken. 
http://wjst.wu.ac.th

\section{Results and discussion}

\section{Toxicity test for lethal concentration}

For the test of a range lethal concentration at $96 \mathrm{~h}$, only $5 \%$ of fish dead at $0 \mathrm{ppb}$, whereas the minimum concentration which caused a $100 \%$ death was $6 \mu \mathrm{g} / 1$ (Table 1). Therefore, a value of $6 \mu \mathrm{g} / 1$ was used as a maximum concentration of cypermethrin for subsequent analyses.

For findings of $\mathrm{LC}_{50}$ and $\mathrm{LC}_{70}$, no mortality was observed in the control group. The mortality of fish seemed to increase gradually when the concentration increased. The complete mortality rate was observed in the experiment with $6 \mu \mathrm{g} / \mathrm{l}$ of cypermethrin (Table 2). The probit analysis of such data revealed that the calculated $96 \mathrm{~h} \mathrm{LC}_{50}$ and $\mathrm{LC}_{70}$ values were at 3.24 and $4.03 \mu \mathrm{g} / 1$, respectively (Table 3).

\section{Behavioural changes}

The control group behaved in their natural manner in a certain dense school. The fish were also alert even at slighted disturbance. No other irregular behaviours were observed in the control group.

Fish exposed to cypermethrin was observed to exhibit time-course behavioural alterations in relation to the levels of cypermethrin concentration. Initially, the fish showed aggression and hyperactivity. After $24 \mathrm{~h}$, the treated fish showed increase in opercular movement, hyperactivity excitement, and imbalanced swimming activity and fanning. After $48 \mathrm{~h}$ of exposure, the fish exhibited typical piping behaviour and swimming nearer to water surface. After $72 \mathrm{~h}$, surfacing phenomenon was greater and the fish also become sluggish, and their opercular movement started decreasing with increase of exposure concentrations. Finally, it was observed that the fish after exposure to cypermethrin for $96 \mathrm{~h}$ lost their equilibrium and sometimes became motionless at the water surface, followed by drowning to the bottom and succumbed to the toxic with mouth and operculum widely opened.

Table 1 The results of toxicity test for lethal concentration showing the observed number and percentage of mortality of Nile tilapia fry at $96 \mathrm{~h}$ of cypermethrin exposure.

\begin{tabular}{cccc}
\hline Concentration $(\boldsymbol{\mu g} / \mathbf{l})$ & Number of subjects & Number of dead fish & Percentage of mortality (\%) \\
\hline 0 & 20 & 1 & 5 \\
2 & 20 & 8 & 40 \\
4 & 20 & 13 & 75 \\
6 & 20 & 20 & 100 \\
8 & 20 & 20 & 100 \\
\hline
\end{tabular}

Table 2 The results of definitive toxicity test showing the observed number, percentage of mortality and the probit values of Nile tilapia fry at $96 \mathrm{~h}$ of cypermethrin exposure.

\begin{tabular}{ccccc}
\hline Concentration $(\boldsymbol{\mu g} / \mathbf{l})$ & Number of subjects & Number of dead fish & Percentage of mortality (\%) & Probit value \\
\hline 0 & 30 & 0 & 0 & - \\
1 & 30 & 16 & 53.3 & 0.52256 \\
2 & 30 & 18 & 60.0 & 0.57842 \\
3 & 30 & 20 & 66.7 & 0.72392 \\
4 & 30 & 24 & 80.0 & 0.85333 \\
5 & 30 & 27 & 90.0 & 0.92958 \\
6 & 30 & 30 & 100.0 & 0.96755 \\
\hline
\end{tabular}


http://wjst.wu.ac.th

Table 3 Acute $96 \mathrm{~h}$ toxicity of cypermethrin on fry of Nile tilapia Oreochromis niloticus.

\begin{tabular}{ccccc}
\hline LC value & $\begin{array}{c}\text { Concentration } \\
(\boldsymbol{\mu g} / \mathbf{l})\end{array}$ & $\mathbf{9 5}$ \% confidence limits & Intercept \pm SE & Slope \pm SE \\
\hline $\mathrm{LC}_{1}$ & 1.2491 & $0.0493-2.1660$ & $-0.847044 \pm 0.338424$ & $5.60279 \pm 2.05015$ \\
$\mathrm{~L} C_{5}$ & 1.6529 & $0.1320-2.5654$ & & \\
$\mathrm{LC}_{10}$ & 1.9191 & $0.2223-2.8121$ & \\
$\mathrm{LC}_{20}$ & 2.2994 & $0.4184-3.1516$ & \\
$\mathrm{LC}_{30}$ & 2.6196 & $0.6571-3.4334$ & \\
$\mathbf{L C}_{\mathbf{5 0}}$ & $\mathbf{3 . 2 4 9 6}$ & $\mathbf{1 . 3 6 4 8}-\mathbf{4 . 0 1 5 5}$ & \\
$\mathbf{L} C_{70}$ & $\mathbf{4 . 0 3 1 1}$ & $\mathbf{2 . 6 5 3 6}-\mathbf{5 . 0 1 6 7}$ & \\
$\mathrm{LC}_{80}$ & 4.5924 & $3.5657-6.3869$ & \\
$\mathrm{LC}$ & 4.9752 & $4.0294-7.8594$ & \\
$\mathrm{LC}_{90}$ & 5.5025 & $4.6083-11.5023$ & \\
$\mathrm{~L} C_{95}$ & 6.3886 & $5.1056-17.3706$ & \\
$\mathrm{~L} C_{99}$ & 8.4535 & $6.1875-45.4230$ & \\
\end{tabular}

\section{Histopathological examination}

The alteration of tissue was observed in all internal organs examined including gill, liver and kidney, but not seen on skin. Histological changes in gill tissues were noticed with oedema, desquamation, hyperplasia, degeneration, and fusion of epithelial cells. The abnormalities varied following the rise of cypermethrin concentration and time of exposure (Table 4 and Figure 1). The alteration of liver showed with an unclear hepatocyte boundary, granulation and vacuole formation in cytoplasm, dilation of blood vessels, enlargement of nuclei together with shrinkage of chromatin, and formation of vacuoles and sinusoids. At the highest concentration of cypermethrin at 72 and $96 \mathrm{~h}$, there was no alteration found inside hepatic cells. The severity of the hepatic abnormality depended on concentration of cypermethrin and the time they were exposed to cypermethrin (Table 4 and Figure 2). Histopathological findings in kidney varied along with the concentrations and time of exposure, which characterized by glomeruli dilation, renal tubule vacuolation and degeneration, and the enlargement of afferent and efferent arterioles (Table 4 and Figure 3). Notably, no obvious abnormality was found on skin (Table 4 and Figure 4).

\section{Discussion}

The results of acute toxicity test obtained in the present study revealed that the $\mathrm{LC}_{50}$ and $\mathrm{LC}_{70}$ for 96 h of cypermethrin to fry of Nile tilapia $O$. niloticus were 3.24 and $4.23 \mu \mathrm{g} / \mathrm{l}$, respectively. These findings are in line with previous studies, which discovered that the $\mathrm{LC}_{50}$ values of cypermethrin are diverse in microgram levels to many fish species even at very low level was observed in some fish. Smith and Stratton [11] suggested that the $48 \mathrm{~h} \mathrm{LC}_{50}$ of cypermethrin to bluegill sunfish Lepomis macrochirus, desert puff-fish Cyprinodon macularis, and mosquito fish Gambusia affinis were at 1.8, 6.0 and 8.0 $\mu \mathrm{g} / \mathrm{l}$, respective. Bradbury and Coats [8] reviewed the acute toxicity of cypermethrin to many fish species and informed that the $96 \mathrm{~h} \mathrm{LC}_{50}$ values in some fish were very low levels such as $0.4 \mu \mathrm{g} / 1$ for Scardinius erythropthalmus, $0.9 \mu \mathrm{g} / \mathrm{l}$ for common carp Cyprinus carpio, $1.2 \mu \mathrm{g} / 1$ for brown trout Salmo trutta, and $2.0 \mu \mathrm{g} / \mathrm{l}$ for Atlantic salmon Salmo salar. Saha and Kaviraj [19] also found that the $96 \mathrm{~h} \mathrm{LC}_{95}$ of cypermethrin in catfish Heteropneustus fossilis was low as $0.67 \mu \mathrm{g} / 1$.

Various previous studies also suggested that the relative higher tolerance to cypermethrin were observed in many fish species. The present study showed that Nile tilapia, $O$. niloticus is more sensitive to cypermethrin than some fish such as guppy Poecilia reticulata $\left(96 \mathrm{~h} \mathrm{LC} \mathrm{LC}_{50}=21.4 \mu \mathrm{g} / \mathrm{l}\right)$ [20], 
Nemacheilus aureus $\left(96 \mathrm{~h} \mathrm{LC}_{50}=30 \mu \mathrm{g} / \mathrm{l}\right)$, and rainbow trout Oncorhynchus mykiss $\left(96 \mathrm{~h} \mathrm{LC}_{50}=31.4\right.$ $\mu \mathrm{g} / \mathrm{l})[21]$.

Table 4 Abnormality levels in gill, liver, kidney and skin after cypermethrin exposure at different concentrations of $0,24,48,72$ and $96 \mathrm{~h}$.

\begin{tabular}{|c|c|c|c|c|c|c|c|c|c|c|c|c|c|c|c|c|c|c|c|}
\hline \multirow[b]{2}{*}{$\begin{array}{c}\text { Concentratio } \\
\mathbf{n}\end{array}$} & \multirow[b]{2}{*}{$\underset{\mathbf{e}}{\operatorname{Tim}}$} & \multicolumn{4}{|c|}{ Gill } & \multicolumn{5}{|c|}{ Liver } & \multicolumn{5}{|c|}{ Kidney } & \multicolumn{4}{|c|}{ Skin } \\
\hline & & 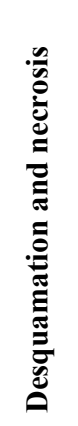 & 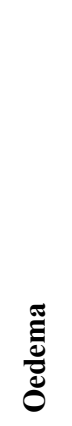 & 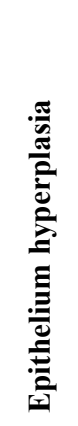 & 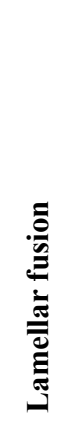 & 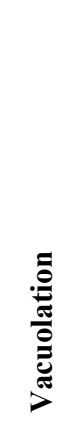 & 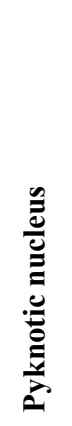 & $\frac{\frac{n}{0}}{\frac{2}{2}}$ & 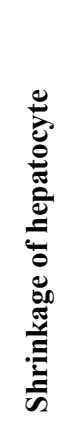 & 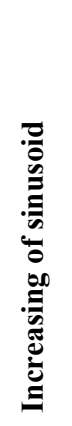 & 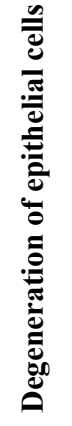 & 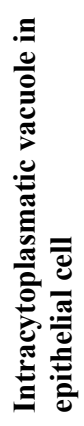 & 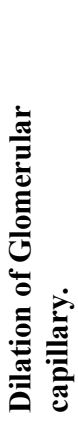 & 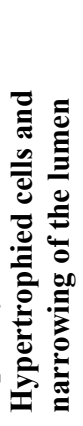 & 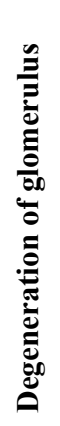 & 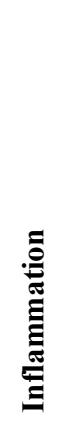 & 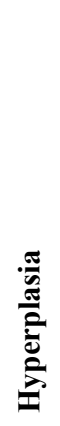 & & لِّ \\
\hline Control & - & + & $+/-$ & - & - & - & - & - & - & - & - & - & - & - & - & - & - & - & - \\
\hline \multirow[t]{4}{*}{$\mathrm{LC}_{50}$} & $24 \mathrm{~h}$ & ++ & ++ & + & + & + & + & - & - & + & - & - & + & + & - & - & - & - & - \\
\hline & $48 \mathrm{~h}$ & ++ & ++ & ++ & ++ & ++ & + & + & + & ++ & - & + & + & + & - & - & - & - & - \\
\hline & $72 \mathrm{~h}$ & ++ & ++ & + & ++ & ++ & + & ++ & - & + & + & ++ & ++ & ++ & + & - & - & - & - \\
\hline & $96 \mathrm{~h}$ & ++ & ++ & +++ & +++ & +++ & ++ & ++ & ++ & ++ & ++ & ++ & ++ & ++ & + & - & - & - & - \\
\hline \multirow[t]{4}{*}{$\mathrm{LC}_{70}$} & $24 \mathrm{~h}$ & + & ++ & ++ & ++ & + & + & + & + & ++ & - & + & + & + & - & - & - & - & - \\
\hline & $48 \mathrm{~h}$ & ++ & ++ & ++ & +++ & ++ & ++ & ++ & ++ & ++ & + & ++ & + & + & - & - & - & - & - \\
\hline & $72 \mathrm{~h}$ & +++ & +++ & +++ & +++ & +++ & +++ & +++ & +++ & +++ & + & ++ & ++ & ++ & + & - & - & - & - \\
\hline & $96 \mathrm{~h}$ & +++ & +++ & +++ & +++ & +++ & +++ & +++ & +++ & +++ & ++ & +++ & +++ & ++ & ++ & - & - & - & - \\
\hline
\end{tabular}

Denote: - no abnormality,

+ abnormality appearing approximately $30 \%$,

++ abnormality appearing approximately $30-70 \%$,

+++ abnormality appearing approximately $70-100 \%$ 


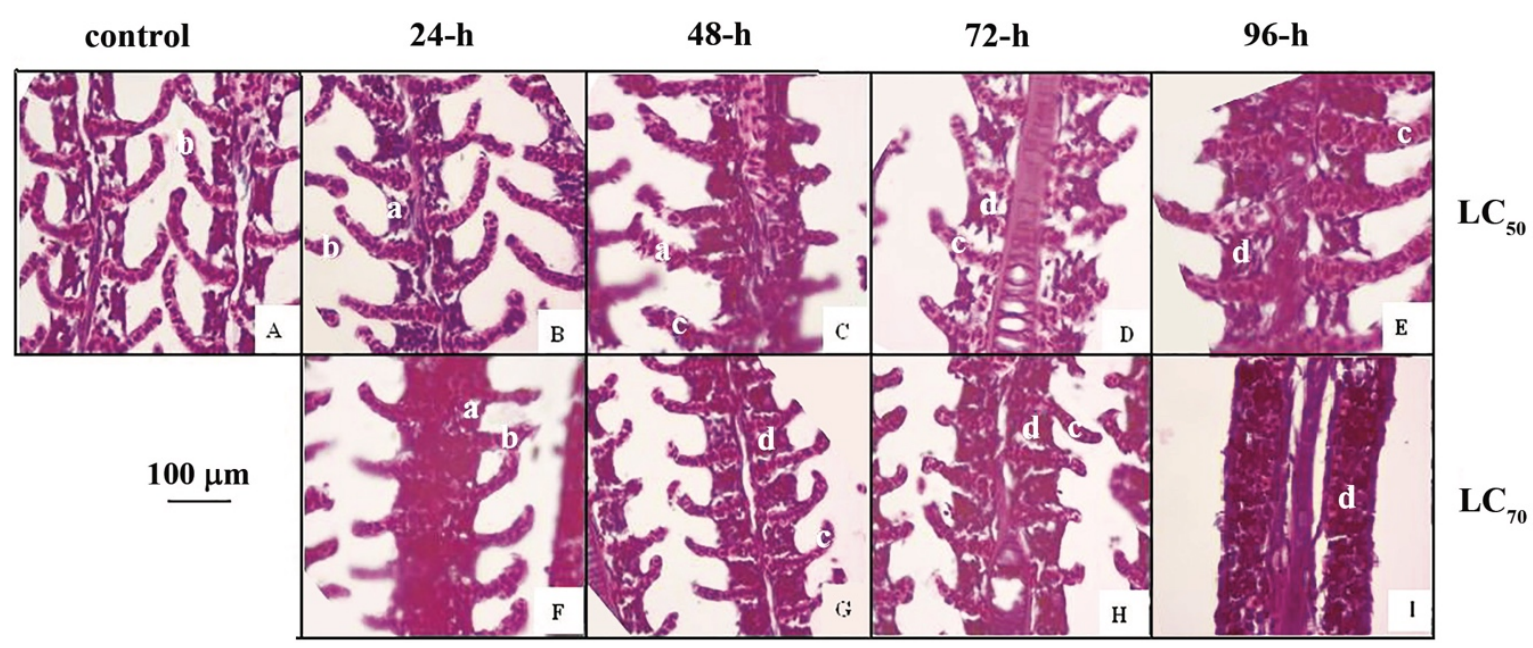

Figure 1 Histopathological appearance in gill of different concentrations at 0, 24, 48, 72 and $96 \mathrm{~h}$ ( $a=$ desquamation, $b=$ oedema, $c=$ hyperplasia, $d=$ fusion of lamellae).

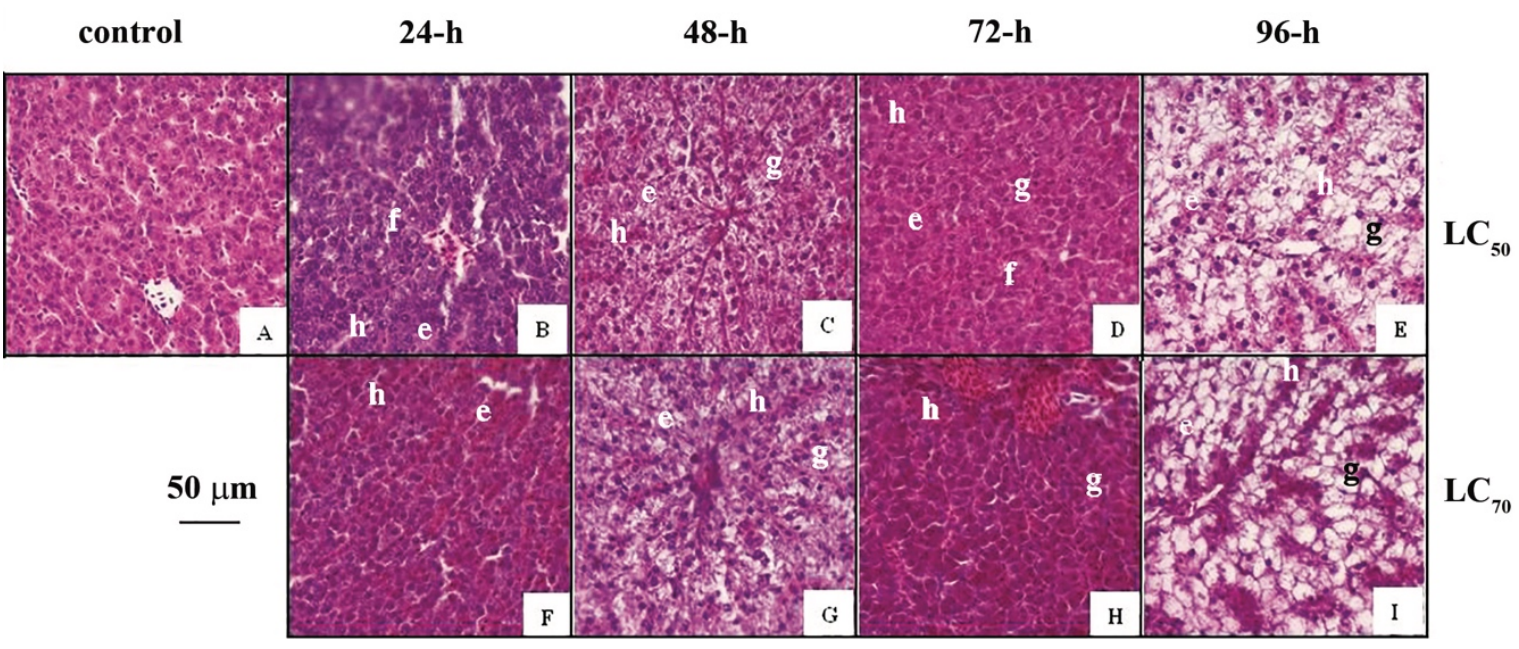

Figure 2 Histopathological characters of gill of different concentrations at $0,24,48,72$ and $96 \mathrm{~h}(\mathrm{e}=$ vacuolation, $\mathrm{f}=$ pyknotic nucleus, $\mathrm{g}=$ cytolysis, $\mathrm{h}=$ increasing of sinusoid). 


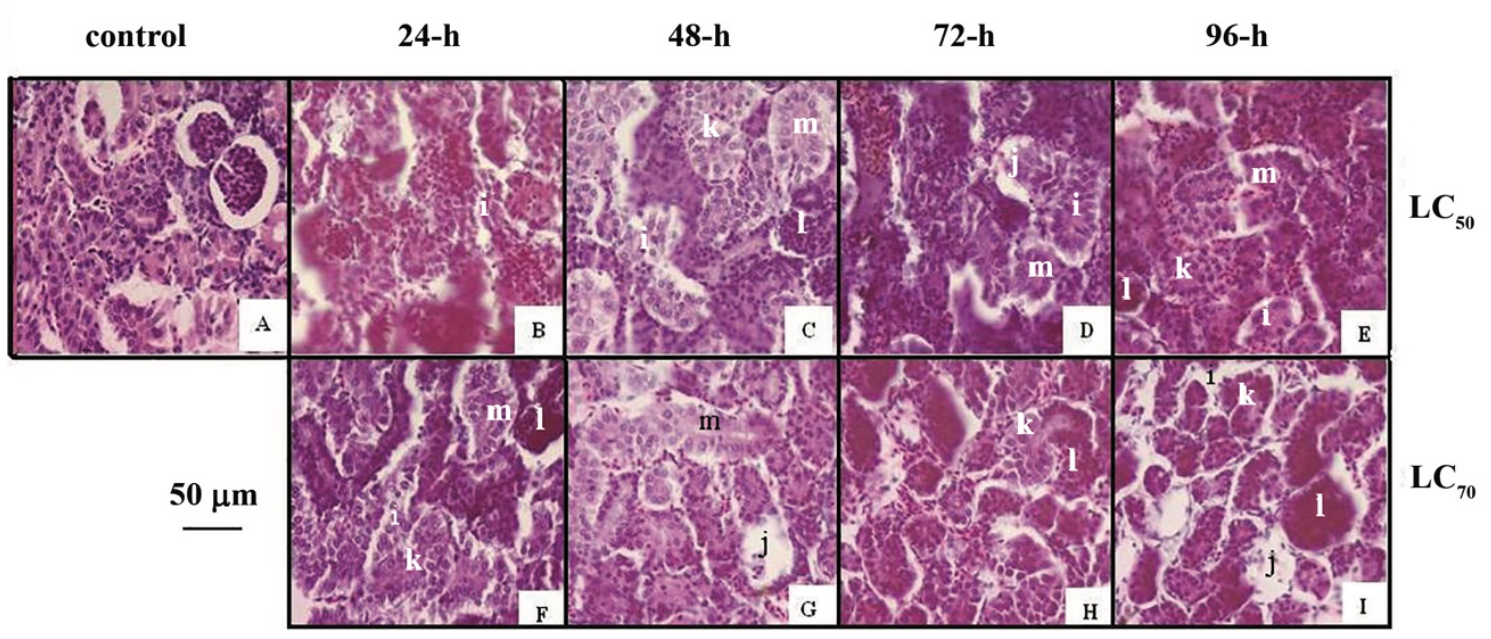

Figure 3 Histopathological appearance of kidney at different concentration at 0, 24, 48, 72 and $96 \mathrm{~h}(\mathrm{i}=$ degeneration of epithelial cell, $\mathrm{j}=$ intracytoplasmic vacuole, $\mathrm{k}=$ dilation, $\mathrm{l}=$ hypertrophied cell, $\mathrm{m}=$ degeneration of glomerulus).

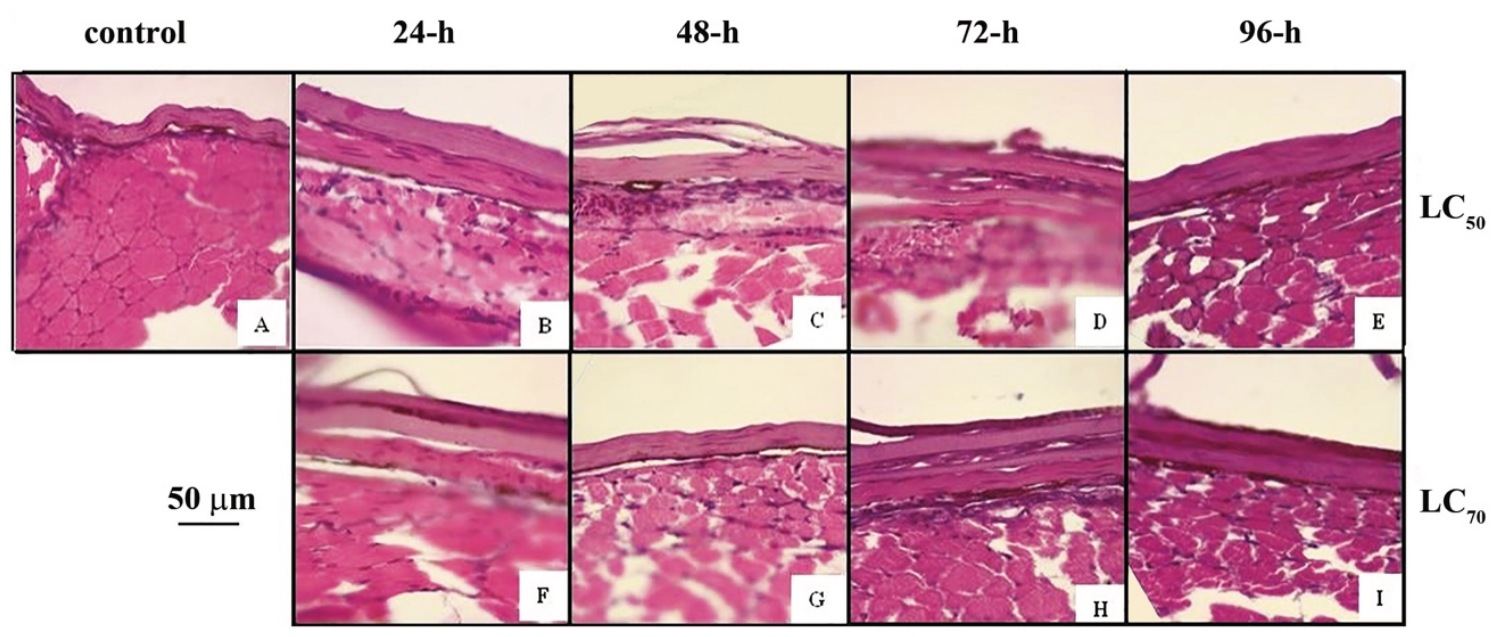

Figure 4 Histopathological appearance of skin at different concentration at 0, 24, 48, 72 and 96 h. 
Diverse values of cypermethrin toxicity to $O$. niloticus were found. The $96 \mathrm{~h} \mathrm{LC}_{50}$ observed here is higher than the report of Bradbury and Coats [8], which documented that $\mathrm{LC}_{50}$ of cypermethrin to tilapia was $2.2 \mu \mathrm{g} / \mathrm{l}$. The present study also showed that tilapia fry is more sensitive to cypermethrin than adult, which had $96 \mathrm{~h} \mathrm{LC}_{50}$ at $5.99 \mu \mathrm{g} / 1$ [22]. The variation in toxicity levels of cypermethrin were also found in rainbow trout Oncorhynchus mykiss that the $96 \mathrm{~h} \mathrm{LC}_{50}$ of cypermethrin to this species ranged of $2.28-8.2$ $\mu \mathrm{g} / 1[8,11,23]$. The results are also consistent with the case of common carp Cyprinus carpio that Reddy and Bashamohideen [24] reported. This study reported a $48 \mathrm{~h} \mathrm{LC}_{50}$ value of cypermethrin as $70 \mu \mathrm{g} / \mathrm{l}$, which is much higher than the value recorded by Bradbury and Coats [8]. These findings are in line with several previous studies which proposed that cypermethrin appear to be more toxic to smaller fish than larger ones $[25,26]$.

The varieties in toxicity levels of cypermethrin to the same species will be influenced by various factors such as chemical composition of pesticide, exposed condition, water quality, and size, age and variety of fish sample. Most commercial products of cypermethrin are mixture of its isomers, which subsequently influenced the toxicity levels $[8,19]$. Solubility and Stability are considered as important factors, which are related to the toxicity of pesticides. Cypermethrin is likely to persist in water for longer duration than other pyrethroids [10]. In addition, water temperature contributed to the levels of toxicity. Many previous studies found that pyrethroids are toxic to fish at lower temperature rather than higher temperature [25-27].

The behavioural examination revealed that cypermethrin affects behaviour of fish including erratic movement, inequality movement, increasing of opercular activity and moving to water surface to take some air. Even at low concentration of $2 \mu \mathrm{g} / \mathrm{l}$, fish exhibited an irregular movement and an increased in their visit to water surface. It will be supposed that all those behaviours were a result from the mode of action of cypermethrin as a neurotoxin [28], that subsequently caused fish to be excited, anxious and an unbalanced movement [21,29].

Histopathological appearances of gill after they were exposed with cypermethrin at $\mathrm{LC}_{50}$ and $\mathrm{LC}_{70}$ for $96 \mathrm{~h}$ were desquamation, oedema, hyperplasia and fusion of secondary lamellae. In addition, there are accumulation of blood cells and a decrease of gill surface area. As it is well known that gills play an important role in respiration, acid-base balance, osmoregulation and excretion of nitrogenous wastes of fish [30]. Gills also remain in close interaction with the external environment. It likely to be a primary target organ which is highly sensitive to contaminants in water [31]. Desquamation, oedema and hyperplasia of secondary lamellae are considered as an indicative of respiratory trouble in fish, which subsequently caused the fish to move more active than usual, which could lead to an increased in frequency of surface visit for an increase in the oxygen exchange rate $[31,32]$. The presence of gill oedematous hyperplasia is possibly due to increase of capillary permeability [33]. The fusion of some secondary lamellae leads to the increase of the distance between the external environment and blood, which assisted as a barrier to the penetration of contaminant into blood [31]. The severity of gill abnormality is correlated to the increase of concentration and time exposed to cypermethrin. These observations are consistent with numerous earlier studies in various fish species such as the toxicity study of cypermethrin to common carp Cyprinus carpio [32], the acute sub-lethal toxicity test of deltamethrin to common carp Cyprinus carpio [34] as well as the study on effect of lambda-cyhalotrin to Cirrhinus mrigala [35].

Histological changes of liver after the fish were exposed to cypermethrin at $\mathrm{LC}_{50}$ and $\mathrm{LC}_{70}$ are vacuolation, pyknotic nuclei, necrosis and enlargement of sinusoids. The histopathological changes observed in the present study may be attributed to the direct influence of cypermethrin on hepatocytes, since liver is a recognised organ which plays a vital role in uptake, biotransformation and detoxification of foreign compound [36]. It is also considered as the organ which is mostly affected by contaminants in water [31]. The existence of vacuolated cells is possibly to be an indication of fatty degeneration [32]. The hepatocytic vacuolations is a common response to toxic chemical in fish, which might be associated with inequity between the rates of substance synthesis in parenchyma cells and their releasing into the 
http://wjst.wu.ac.th

circulation [37]. Necrosis of the liver tissue may be resulted from the excessive works to dispose of toxicant from the body during the detoxification process. The incapability to regenerate new liver cells may also lead to necrosis [32,37]. The presence of pyknotic nuclei supposes that the changes of nucleus are induced by the trophy and necrosis of hepatocytes, which are related to the cell metabolic activity $[38,39]$. Prolonged accumulation of cypermethrin will cause a condensation of nucleolar materials, leading to the formation of darkly stained pyknotic nuclei [32,39]. In addition, the enlargement of hepatic sinusoids is possibly a revealing of enormous detoxification of cypermethrin since all toxicants are transferred to detoxicate in liver from hepatic portal vein through hepatic sinusoids.

The results also showed that cypermethrin exposure induced enlargement and degeneration of epithelial cells of renal tubules. Glomerulus together with afferent and efferent arterioles is also damaged. The swelling of renal tubules can be identified by hypertrophy of the epithelial cells and the presence of small granules in cytoplasm [32]. The degeneration of renal cells may be indicated by the damage in renal corpuscles, which can lead to necrosis of renal tissue [40] The similar observations were reported in various fish exposed to different pesticides [35,41-43].

Although several studies demonstrated the high susceptibility of skin to environmental pollutant impacts [44-47], there is no significant histological abnormality found on the skin of Nile tilapia exposed to cypermethrin after stained with $\mathrm{H} \& \mathrm{E}$ staining. More advanced techniques still need to identify histological changes and chemical substance inside cells by using specific staining.

In summary, the present study suggests that even the less toxicity of cypermethrin when compared with the other group of insecticides such as organophosphate, the effects still appear as some histological changes in certain internal organs of tilapia fry including gill, kidney and liver. According to the widely use of cypermethrin in agricultural area throughout Thailand, long-term monitoring of cypermethrin contamination in aquatic ecosystems is also necessary. Hopefully, the histopathological findings in the tilapia fry in the recent work can be of use as an indicator for chemical residues in natural water resource.

\section{Acknowledgements}

The present work was financially supported by the Development and Promotion of Science Talents (DPST) Project, granted by the Institute for the Promotion of Teaching Science and Technology (IPST). We would like to thank Department of Biology, Faculty of Science, Khon Kaen University for the support by providing necessary facility. We also thank the anonymous reviewers for their comments to improvement of the manuscript.

\section{References}

[1] Food and Agriculture Organisation of the United Nations (FAO). FAO Fisheries \& Aquaculture Cultured Aquatic Species Information Programme - Oreochromis niloticus (Linnaeus, 1758). Available at: http://www.fao.org/fishery/culturedspecies/Oreochromis_niloticus/en, accessed February 2017.

[2] VB Santos, EA Mareco and MDP Silva. Growth curves of Nile tilapia (Oreochromis niloticus) strains cultivated at different temperatures. Acta Sci. Anim. Sci. 2013; 35, 235-42.

[3] Department of Fisheries. Fisheries Statistics of Thailand 2013. Information and Communication Technology Centre, Department of Fisheries, Ministry of Agriculture and Cooperatives, Bangkok, 2015.

[4] A Thapinta and PF Hudak. Pesticide use and residual occurrence in Thailand. Environ. Monit. Assess 2000; 60, 103-14.

[5] P Panuwet, W Siriwong, T Prapamontol, PB Ryan, N Fiedler, MG Robson and DB Barr. Agricultural pesticide management in Thailand: Status and population health risk. Environ. Sci. Policy 2012; 17, 72-81.

[6] D Bucke. Aquatic pollution: Effects on the health of fish and shellfish. Parasitology 1993; 106, S25-S37.

[7] B Austin. The effects of pollution on fish health. J. Appl. Microbiol. 1998; 85, 234S-242S. 
http://wjst.wu.ac.th

[8] SP Bradbury and JR Coats. Comparative toxicology of the pyrethroid insecticides. Rev. Environ. Contam. Toxicol. 1989; 108, 133-77.

[9] A Tawatsin, U Thavara and P Siriyasatien. Pesticides used in Thailand and toxic effects to human health. Med. Res. Arch. 2015; 1, 3.

[10] H Jin and GRB Webster. Persistence, penetration, and surface availability of cypermethrin and its major degradation products in Elm Bark. J. Agric. Food Chem. 1998; 46, 2851-7.

[11] TM Smith and GW Stratton. Effects of synthetic pyrethroid insecticides on nontarget organisms. Residue Rev. 1986; 97, 93-120.

[12] R Edwards, P Millburn and DH Hutson. Comparative toxicity of cis-cypermethrin in rainbow trout, frog, mouse, and quail. Toxicol. Appl. Pharmacol. 1986; 84, 512-22.

[13] B Sarkar, A Chatterjee, S Adhikari and S Ayyappan. Carbofuran- and cypermethrin-induced histopathological alterations in the liver of Labeo rohita (Hamilton) and its recovery. J. Appl. Ichthyol. 2005; 21, 131-5.

[14] N Korkmaz, EI Cengiz, E Unlu, E Uysal and M Yanar. Cypermethrin-induced histopathological and biochemical changes in Nile tilapia (Oreochromis niloticus), and the protective and recuperative effect of ascorbic acid. Environ. Toxicol. Pharmacol. 2009; 28, 198-205.

[15] DL Reish, JS Gray and PS Oshida. Manual of Methods in Aquatic Environment Research. Pt. 10: Short-term Static Bioassays. FAO, Rome, 1987.

[16] EW Rice and American Public Health Association. Standard Methods for the Examination of Water and Wastewater. 22 ${ }^{\text {nd }}$ ed. American Public Health Association, Washington DC, 2012.

[17] DJ Finney. Probit Aalysis. $3^{\text {rd }}$ ed. Cambridge University Press, London, 1971.

[18] T Postelnicu. Probit Analysis. In: M Lovric (Ed.). International Encyclopedia of Statistical Science. Springer Berlin Heidelberg, Berlin, 2011, p. 1128-31.

[19] S Saha and A Kaviraj. Acute toxicity of synthetic pyrethroid cypermethrin to freshwater catfish Heteropneustes fossilis (Bloch). Int. J. Toxicol. 2003; 22, 325-8.

[20] H Polat, FÜ Erkoç, R Viran and O Koçak. Investigation of acute toxicity of beta-cypermethrin on guppies Poecilia reticulata. Chemosphere 2002; 49, 39-44.

[21] J Velisek, T Wlasow, P Gomulka, Z Svobodová, R Dobšíková, L Novotný and M Dudzik. Effects of cypermethrin on rainbow trout (Oncorhynchus mykiss). Vet. Med. (Praha) 2006; 10, 469-76.

[22] R Sarikaya. Investigation of acute toxicity of alpha-cypermethrin on adult Nile tilapia (Oreochromis niloticus L.). Turk. J. Fish. Aquat. Sci. 2009; 9, 85-9.

[23] SMS Veni and K Veeraiah. Toxicity effect of cypermethrin (10\% EC) to the freshwater fish Cirrinus mrigala (Hamilton). Int. J. Pure Appl. Zool. 2014; 2, 365-72.

[24] PM Reddy and MD Bashamohideen. Toxicity of synthetic pyrethroid insecticides fenvalerate and cypermethrin to the fish Cyprinus carpio. Environ. Ecol. 1989; 7, 1016-8.

[25] WL Mauck, LE Olson and LL Marking. Toxicity of natural pyrethrins and five pyrethroids to fish. Arch. Environ. Contam. Toxicol. 1976; 4, 18-29.

[26] IR Hill. Effects on Nontarget Organisms in Terrestrial and Aquatic Environments. In: JP Lehey (Ed.). The Pyrethroid Insecticides. Taylor \& Francis, London, 1985, p. 165-81.

[27] S Başer, F Erkoç, M Selvi and O Koçak. Investigation of acute toxicity of permethrin on guppies Poecilia reticulata. Chemosphere 2003; 6, 469-74.

[28] B Giray, A Gürbay and F Hincal. Cypermethrin-induced oxidative stress in rat brain and liver is prevented by vitamin E or allopurinol. Toxicol. Lett. 2001; 118, 139-46.

[29] K Haya. Toxicity of pyrethroid insecticides to fish. Environ. Toxicol. Chem. 1989; 8, 381-91.

[30] DH Evans. The multifunctional fish gill: Dominant site of gas exchange, osmoregulation, acid-base regulation, and excretion of nitrogenous waste. Physiol. Rev. 2005; 85, 97-177.

[31] MMP Camargo and CBR Martinez. Histopathology of gills, kidney and liver of a Neotropical fish caged in an urban stream. Neotropical Ichthyol. 2007; 5, 327-36.

[32] P Neelima, CLA Kumar, JCS Rao and NG Rao. Histopathological alterations in Gill, Liver and Kidney of Cyprinus carpio (Linn.) exposed to Cypermethrin (25\%EC). Int. J. Adv. Res. Biol. Sci. 2015; 2, 34-40. 
http://wjst.wu.ac.th

[33] EAA Olojo, KB Olutin, G Mbaka and AD Oluwemimo. Histopathology of the gill and liver tissues of the African catfish Clarias gariepinus exposed to lead. Afr. J. Biotechnol. 2005; 4, 117-22.

[34] EI Cengiz. Gill and kidney histopathology in the freshwater fish Cyprinus carpio after acute exposure to deltamethrin. Environ. Toxicol. Pharmacol. 2006; 22, 200-4.

[35] B Velmurugan, M Selvanayagam, EI Cengiz and E Unlu. Histopathology of lambda-cyhalothrin on tissues (gill, kidney, liver and intestine) of Cirrhinus mrigala. Environ. Toxicol. Pharmacol. 2007; 24, 286-91.

[36] M Gernhöfer, M Pawert, M Schramm, E Müller and R Triebskorn. Ultrastructural biomarkers as tools to characterize the health status of fish in contaminated streams. J. Aquat. Ecosyst. Stress Recovery 2001; 8, 241-60.

[37] WH Gingerich. Hepatic Toxicology of Fishes. In: LJ Weber (Ed.). Aquatic Toxicology. Raven Press, New York, 1982, p. 55-105.

[38] WS Fernandez, JF Dias, CAO Ribeiro and JDS Azevedo. Liver damages and nuclear abnormalities in erythrocytes of Atherinella brasiliensis (Actynopterigii, Atherinopsidade) from two beaches in Southeast of Brazil. Braz. J. Oceanogr. 2011; 59, 163-9.

[39] BM Jarrar and NT Taib. Histological and histochemical alterations in the liver induced by lead chronic toxicity. Saudi. J. Biol. Sci. 2012; 19, 203-10.

[40] E Ayotunde, O Fagbenro and O Adebayo. Histological changes in Oreochromis niloticus (Linnaeus I779) exposed to aqueous extract of Moringa oleifera seeds powder. Turk. J. Fish. Aquat. Sci. 2011; 11, 37-43.

[41] B Velmurugan, T Mathews and EI Cengiz. Histopathological effects of cypermethrin on gill, liver and kidney of fresh water fish Clarias gariepinus (Burchell, 1822), and recovery after exposure. Environ. Technol. 2009; 30, 1453-60.

[42] H Boran, I Altinok and E Capkin. Histopathological changes induced by maneb and carbaryl on some tissues of rainbow trout, Oncorhynchus mykiss. Tissue Cell 2010; 42, 158-64.

[43] E Capkin, E Terzi, H Boran, I Yandi and I Altinok. Effects of some pesticides on the vital organs of juvenile rainbow trout (Oncorhynchus mykiss). Tissue Cell 2010; 42, 376-82.

[44] B Das and S Mukherjee. A histopathological study of carp (Labeo rohita) exposed to hexachlorocyclohexane. Vet. Arh. 2000; 70, 169-80.

[45] DH Baldwin, JA Spromberg, TK Collier and NL Scholz. A fish of many scales: Extrapolating sublethal pesticide exposures to the productivity of wild salmon populations. Ecol. Appl. 2009; 19, 2004-15.

[46] AS Oluwatoyin. Histopathology of Nile Tilapia (Oreochromis niloticus) juveniles exposed to aqueous and ethanolic extracts of Ipomoea aquatica leaf. Int. J. Fish. Aquac. 2011; 3, 244-57.

[47] SE Abalaka, MY Fatihu, NDG Ibrahim and SF Ambali. Gills and skin histopathological evaluation in African sharptooth catfish, Clarias gariepinus exposed to ethanol extract of Adenium obesum stem bark. Egypt. J. Aquat. Res. 2015; 41, 119-27. 